\title{
Organizational Culture: An Islamic Perspective
}

\author{
Muath Eleswed, Ph.D. \\ American University of Kuwait, , Kuwait
}

Email:meleswed@gmail.com

\begin{abstract}
This paper discusses the concept of organizational culture from Western and Islamic perspective. Building on the teaching of Islam, an Islamic Organizational Culture Model was introduced. As fundamentals, the model included sixteen Islamic cultural values. These values include Tawhid, Unity of Purpose, Belief in the Hereafter, Reward and Punishment, Independece, Responsibility and Accountability, Participation, Justice, Dignity, Respect, and Privacy, Trust, Dialouge, Cost efficiency, Time efficiency, Caring and Sharing, Mercy towards Humans, Animals, and the Environment, Eagerness to Learn, and Collectiveness. The paper reveals the outcomes of implementing the model and their significance.
\end{abstract}

Keywords: Islam; Islamic Organizational Culture; Organizational Culture; Values.

\section{Introduction}

Traditionally speaking, from the Western perspective, the concept of organizational culture is rooted in cultural anthropology. Whenever humans exist, societal cultures exist along with them, a situation which is similar to organizations. That is, whenever organizations exist, organizational cultures exist along with them as well. Typically, these cultures are cascaded down from generation to generation of the organizational personnel (Nelson, 2013). Additionally, the concept of organizational culture can be traced back to the Hawthorne studies in which work group culture was described. Moreover, in the early 1970s, managers and researchers meticulously began to stress this concept in order to find better ways for organizations' survival in the utmost dynamically competitive and turbulent environments. As a result, researchers and organizational executives, up to date, agree that organizational cultures do exist, are unique, and can be managed (Gardner, 1985).

According to Schein (1985), three levels of organizational culture exist, including 1) the unconscious and invisible assumptions, which include the environmental relationship, human relationships, human nature, human activities, space, time, and reality; 2) the values which include the espoused values and enacted values; and, 3) the visible artifacts which include the personal enactment, ceremonies and rites, stories, rituals, and symbols.

Throughout the years, several definitions of organizational culture have been introduced. The majority of them however do agree that several levels of cultures exist and differ in terms of their visibility and ability to be altered (Nelson, 2013). Perhaps the simplest definition of organizational culture is "the way things are done" (Apaydin, Jones, George, \& Belkhodja, 2017). Based on these three levels of organizational culture introduced by Schein (1985), he de- 
fines organizational culture as the valid assumptions which organizational personnel learn and teach the new personnel as the way to perceive, think, and feel in the organization. According to Smircich (1983), organizational culture is a system of shared values and beliefs from which norms and behaviors stem.

The organizational culture has been viewed as a mechanism for defining the organizational value system and behavior, thus, the organizational culture significantly impacts favorite organizational outcomes as well as the processes through which these outcomes are attained (Harrison \& Corley, 2011). According to Jabnoun (2005), “cultural theory of organizational effectiveness takes as its foundation the notion that the values, beliefs, and meanings that underlie a social system are the primary source of motivated and coordinated activity" and thus, organizational culture is considered as a significant determent of organizational commitment. Positive organizational cultures, which are not easy to mimic by competitors, tend to sustain organizational competitive advantages. However, for organizational cultures to be positive and have positive impacts on their organizations, they need to be aligned with their organizational strategies. Thus, the choice is either to fit the organizational strategy into the organizational culture or vice-versa. Practically, it is easier, more effective, and more efficient to fit the organizational strategy into the organizational culture. Furthermore, organizational cultures can be seen as motivators and coordinators of organizational activities (Barney, 1986).

Leaders of organizations play significant roles in shaping and reinforcing organizational cultures (Schein, 1985). According to Kets and Miller (1986), organizational cultures are seen as extensions and personalities of their respective chief officers and thus, they foster either negative or positive organizational cultures. Leaders are significantly important to organizations as they are perceived as organizational culture makers and change agents (Denison, 1990). When organizational leaders are the founders, most likely they will instill their own organizational cultures which are based on their own personal values and attitudes. Typically, the founders possess a comprehensive look out for the future of their organizations, where they are heading to, their dominant cultures, their missions, goals, and objectives, and their overall organizational strategies. Because, the founders often oversee the preliminary hiring in their organizations, when it comes to hiring new members, most likely, the ones who are selected are the ones who fit best in the existing organizational cultures. Finally, once the founders finalize setting their organizational cultures, which will become hard to change, they communicate their values and attitudes throughout their organizations to reach all current and prospective members. As a consequence, all members, current and potential, usually will have to conform to the predetermined organizational cultures by their corresponding founders (Jabnoun, 2005).

The purpose of this paper is to introduce the concept of organizational culture from an Islamic perspective which is geared towards Muslims and Muslim owned organizations. In the subsequent sections of this paper, the pre-Islamic culture, will, briefly, be commented on, the Islamic Organizational Culture Model will be introduced and explained in detail, and, the outcomes of implementing this model will be presented. Sixteen culture-based values of the Companions of the Prophet Muhammad [Blessings and Peace be upon him], will be used as the foundations for developing the Islamic Organizational Culture Model. Throughout the paper, references - pieces of evidence-will be made to the English translation ${ }^{(1)}$ of the verses in the Holy Qur'an and the Hadith (the sayings) of the Prophet Muhammad [Blessings and Peace be upon him].

1 The Noble Qur'an https://quran.com and Qur'an https://legacy.quran.com/ were used for translation. For the Hadith, several Hadith English-based sites were used, including Sunnah.com and Google Translate. 


\section{Pre-Islamic Culture}

Islam as a religion is universal and was revealed to all mankind. Thus, it is not restricted to a particular nation, race, or gender. The Prophet Muhammad [Blessings and Peace be upon him] was sent by Allah as a mercy to all mankind. In the Holy Qur'an, Allah Says \{And We have not sent you, [O Muhammad], except as a mercy to the worlds\} (Qur'an 21: 107). It is well noted that the early Muslims success is largely attributed to their Islamic culture. Albeit, the pre-Islamic cultural values consisted of certain elements which were contradictory to Islam, such as idol worshipping and low image of men among others, yet, many others were compatible such as generosity, directness, and courage. However, Islam abrogated the contradicting elements of the pre-Islamic cultural values and replaced them with non-contradicting ones. Moreover, the inception of Islam had resulted in the emergence of a holistic, coherent, and pure set of values-based culture. As discussed earlier, leaders have a significant role in creating their organizational cultures, thus, the presence of the Prophet Muhammad [Blessings and Peace be upon him] played a vital role in forming the Islamic culture of his Companions. Additionally, he [Blessings and Peace be upon him] played a pivotal role in the purification, completion, and complementary of the cultural values and practices of his Companions (Jabnoun, 2005). In the Hadith, the Prophet [Blessings and Peace be upon him] said "I have been sent to perfect good character" (al-Muwatta: 1614) ${ }^{(2)}$.

\section{The Islamic Organizational Culture Model}

The development of the Islamic Organizational Culture Model presented in here is, (Figure 1), merely based on the cultural values of the Companions of the Prophet Muhammad [Blessings and Peace be upon him]. Prior to embracing Islam, these Companions possessed numerous positive cultural values. However, when Islam came, it not only maintained these values and considerably reinforced them, but, it integrated them into a greater system of value and belief which is characterized by having a precise structure and direction. As a result, the success of the Companions is attributed to their cultural values which were taught by their leader, Prophet Muhammad [Blessings and Peace be upon him] (Jabnoun, 2005). In the Holy Qu'ran, Allah Says about his Prophet Muhammad [Blessings and Peace be upon him]: \{And indeed, you are of a great moral character\} (Qur'an 68: 4). As shown in Appendix A, the Islamic Organizational Culture Model consists of sixteen elements. These include Tawhid, Unity of Purpose, Belief in the Hereafter, Reward, and Punishment, Independece, Responsibility and Accountability, Participation, Justice, Dignity, Respect, and Privacy, Trust, Dialouge, Cost efficiency, Time efficiency, Caring and Sharing, Mercy towards Humans, Animals, and the Environment, Eagerness to Learn, and Collectiveness. Subsequently, each one of the aforementioned elements will be explained in detail.

\section{Tawhid}

The essence of the culture of the Companions of the Prophet Muhammad [Blessings and Peace be upon him] is Tawhid which they learnt it, understood it, believed in, and acted upon it in every aspect of their lives. Tawhid is the belief in the unification of the divine, the unification of Godliness, and the unification of the Names and Attributes of Allah.

The unification of the divine is the belief in one God and that there is no God worthy of worship except Allah. In the Holy Qur'an, Allah States: \{That is because Allah is the Truth, and 
that which they call upon other than Him is falsehood, and because Allah is the Most High, the Grand\} (Qur'an 22: 62), \{Say, “He is Allah, [who is] One, Allah, the Eternal Refuge, He neither begets nor is born, Nor is there to Him any equivalent\} (Qur'an 112: 1-4), \{Allah - there is no deity except Him, the Ever-Living, the Sustainer of [all] existence. Neither drowsiness overtakes Him nor sleep. To Him belongs whatever is in the heavens and whatever is on the earth. Who is it that can intercede with Him except by His permission? He knows what is [presently] before them and what will be after them, and they encompass not a thing of His knowledge except for what He wills. His Kursi extends over the heavens and the earth, and their preservation tires Him not. And He is the Most High, the Most Great\} (Qur'an 2: 255), \{And they were not commanded except to worship Allah, [being] sincere to Him in religion, inclining to truth, and to establish prayer and to give Zakah. And that is the correct religion\} (Qur'an 98: 5), \{Indeed, We have sent down to you the Book, [O Muhammad], in truth. So worship Allah, [being] sincere to Him in religion\} (Qur'an 39: 2), \{Say, [O Muhammad], "Indeed, I have been commanded to worship Allah, [being] sincere to Him in religion\} (Qur'an 39: 11), \{Say, “Allah [alone] do I worship, sincere to Him in my religion\} (Qur'an 39: 14), \{And your god is one God. There is no deity [worthy of worship] except Him, the Entirely Merciful, the Especially Merciful\} (Qur'an 2: 163), \{So know, [O Muhammad], that there is no deity except Allah and ask forgiveness for your sin and for the believing men and believing women. And Allah knows of your movement and your resting place\} (Qur'an 47: 19).

The unification of Godliness is the belief that Allah is the Creater of everything and $\mathrm{He}$ is the Sustainer, Allah Says: \{That is Allah, your Lord, Creator of all things; there is no deity except Him, so how are you deluded?\} (Qur'an 40: 62), \{And if you asked them, "Who created the heavens and earth?" they would surely say, "Allah."Say, "[All] praise is [due] to Allah"; but most of them do not know\} (Qur'an 31: 25), \{Say, "Who provides for you from the heaven and the earth? Or who controls hearing and sight and who brings the living out of the dead and brings the dead out of the living and who arranges [every] matter?" They will say, "Allah," so say, "Then will you not fear Him?"\} (Qur'an 10: 31), \{That is Allah, your Lord; there is no deity except Him, the Creator of all things, so worship Him. And He is the Disposer of all things\} (Qur'an 6: 102), \{Say, “Who is Lord of the heavens and the earth?" Say, "Allah" Say, "Have you then taken besides Him allies, not possessing [even] for themselves any benefit or any harm?" Say, "Is the blind equivalent to the seeing? Or is darkness equivalent to light? Or have they attributed to Allah partners who created like His creation, so that the creation [of each] seemed similar to them?" Say, "Allah is the Creator of all things, and He is the One, the Prevailing"'\} (Qur'an 13: 16), \{Allah is the Creator of all things, and He is, over all things, Disposer of affairs\} (Qur'an 39: 62).

The unification of the Names and Attributes of Allah is the belief in Allah's Names and Attributes which He and His Prophet Muhammad [Blessings and Peace be upon him] told. In the Holy Qur'an, Allah Says: \{And to Allah belong the best names, so invoke Him by them. And leave [the company of] those who practice deviation concerning His names. They will be recompensed for what they have been doing\} (Qur'an 7: 180), \{He is Allah, other than whom there is no deity, the Sovereign, the Pure, the Perfection, the Bestower of Faith, the Overseer, the Exalted in Might, the Compeller, the Superior. Exalted is Allah above whatever they associate with Him\} (Qur'an 59: 23), \{He is Allah, the Creator, the Inventor, the Fashioner; to Him belong the best names. Whatever is in the heavens and earth is exalting Him. And He is the Exalted in Might, the Wise\} (Qur'an 59: 24).

The Companions understood, believed, and acted upon the aforementioned verses which 
had a positive and profound impact on their daily lives and the development of their culture. As a result, they felt more confident and became more generous and courageous. They understood and believed that, their lives are always in the Hand of Allah the Most Powerful and Who is the Sustainer of this universe and due to that, they became free of any fears except from Allah.

\section{The Unity of Purpose}

Allah Created all mankind for the purpose of worshiping Him. In the Holy Qur'an, Allah Says: \{And I did not create the jinn and mankind except to worship Me\} (Qur'an: 51: 56). Worshipping Allah means that all actions undertaken by mankind should be for the sake of Allah and with a pure intention of pleasing Allah. In the Holy Qur'an, Allah States: \{And they were not commanded except to worship Allah, [being] sincere to Him in religion, inclining to truth, and to establish prayer and to give Zakah. And that is the correct religion\} (Qur'an 98: 5), \{He is the Ever-Living; there is no deity except Him, so call upon Him, [being] sincere to Him in religion. [All] praise is [due] to Allah, Lord of the worlds\} (Qur'an 40: 65), \{So invoke Allah, [being] sincere to Him in religion, although the disbelievers dislike it\} (Qur'an 40: 14), \{Say, [O Muhammad], "Indeed, I have been commanded to worship Allah, [being] sincere to Him in religion\} (Qur'an 39: 11). Focusing on this unity of purpose by all means, leads into a great success in this life and the Hereafter. Additionally, it creates a high level of coherence and efficiency in this life by focusing on a single purpose which is pleasing Allah and as a result, greed is demolished. Further, exercising this unity of purpose means a full commitment to Allah and none but Allah. Thus, intentions and efforts should not be divided between this life and the Hereafter. However, mankind should enjoy the bounties of Allah while this enjoyment is being for the sake of Allah (Jabnoun, 2005). In the Holy Qur'an, Allah Says: \{But seek, through that which Allah has given you, the home of the Hereafter; and [yet], do not forget your share of the world. And do good as Allah has done good to you. And desire not corruption in the land. Indeed, Allah does not like corrupters\} (Qur'an 28: 77).

\section{Belief in the Hereafter, Reward, and Punishment}

Among the culture of the Companions of the Prophet Muhammad [Blessings and Peace be upon him] is believing in the Hereafter in which there will be a reward (entering Paradise), and punishment (entering Hellfire) according to mankind's deeds. This firm belief in the Hereafter and in the reward and punishment system instills a sense of responsibility, accountability, motivation, and self-control. Entering Paradise and avoiding Hellfire was the ultimate long-term goal that the Companions were motivated by and striving to achieve through performing righteous deeds and evading wrong doings (Jabnoun, 2005). In the Holy Qur'an, Allah Says: \{But whoever desires the Hereafter and exerts the effort due to it while he is a believer - it is those whose effort is ever appreciated [by Allah]\} (Qur'an 17: 19), \{Whoever desires the harvest of the Hereafter - We increase for him in his harvest. And whoever desires the harvest of this world - We give him thereof, but there is not for him in the Hereafter any share\} (Qur'an 42: 20), \{And the worldly life is not, but amusement and diversion; but the home of the Hereafter is best for those who fear Allah, so will you not reason?\} (Qur'an 6: 32), \{But as for those who disbelieved and denied Our verses and the meeting of the Hereafter, those will be brought into the punishment [to remain]\} (Qur'an 30: 16), \{And the reward of the Hereafter is better for those who believed and were fearing Allah\} (Qur' an 12: 57), \{Those who denied Our signs and the meeting of the Hereafter - their deeds have become worthless. Are they recompensed except for what they used to do?\} (Qur'an 7: 147), \{Indeed in that is a sign for those who fear the punishment of the Hereafter. That is a Day for which the people will be collected, and that is a Day [which will be] witnessed (Qur'an 11: 103), \{And whoever desires other than Islam as religion - never 
will it be accepted from him, and he, in the Hereafter, will be among the losers\} (Qur'an 3: 85), \{But seek, through that which Allah has given you, the home of the Hereafter; and [yet], do not forget your share of the world. And do good as Allah has done good to you. And desire not corruption in the land. Indeed, Allah does not like corrupters\} (Qur'an 28: 77), \{O my people, this worldly life is only [temporary] enjoyment, and indeed, the Hereafter - that is the home of [permanent] settlement\} (Qur'an 40:39), \{Is one who is devoutly obedient during periods of the night, prostrating and standing [in prayer], fearing the Hereafter and hoping for the mercy of his Lord, [like one who does not]? Say, "Are those who know equal to those who do not know?" Only they will remember [who are] people of understanding\} (Qur'an 39: 9), \{And the eminent among his people who disbelieved and denied the meeting of the Hereafter while We had given them luxury in the worldly life said, "This is not but a man like yourselves. He eats of that from which you eat and drinks of what you drink\} (Qur'an 23: 33), \{Know that the life of this world is but amusement and diversion and adornment and boasting to one another and competition in increase of wealth and children - like the example of a rain whose [resulting] plant growth pleases the tillers; then it dries and you see it turned yellow; then it becomes [scattered] debris. And in the Hereafter is severe punishment and forgiveness from Allah and approval. And what is the worldly life except the enjoyment of delusion.\} (Qur'an 57: 20), \{That is Paradise, which We give as inheritance to those of Our servants who were fearing of Allah\} (Qur'an 19: 63), \{And that is Paradise which you are made to inherit for what you used to do\} (Qur'an 43: 72), \{And Paradise will be brought near [that Day] to the righteous\} (Qur'an 26: 90), \{The companions of Paradise, that Day, are [in] a better settlement and better resting place\} (Qur'an 25: 24), \{Those are the companions of Paradise, abiding eternally therein as reward for what they used to do\} (Qur'an 46: 14), \{But they who believe and do righteous deeds - those are the companions of Paradise; they will abide therein eternally\} (Qur'an 2: 82), \{Every soul will taste death, and you will only be given your [full] compensation on the Day of Resurrection. So he who is drawn away from the Fire and admitted to Paradise has attained [his desire]. And what is the life of this world except the enjoyment of delusion\} (Qur'an 3: 185), \{But those who feared their Lord will be driven to Paradise in groups until, when they reach it while its gates have been opened and its keepers say, "Peace be upon you; you have become pure; so enter it to abide eternally therein," [they will enter]\} (Qur'an 39: 73), \{For those their refuge will be the Fire because of what they used to earn\} (Qur'an 10: 8), \{This is the Fire which you used to deny\} (Qur'an 52: 14), \{And fear the Fire, which has been prepared for the disbelievers\} (Qur'an 3: 131), \{And [mention, O Muhammad], the Day when the enemies of Allah will be gathered to the Fire while they are [driven] assembled in rows\} (Qur'an 41: 19), \{Our Lord, indeed whoever You admit to the Fire - You have disgraced him, and for the wrongdoers there are no helpers\} (Qur'an 3: 192), \{Not equal are the companions of the Fire and the companions of Paradise. The companions of Paradise - they are the attainers [of success]\} (Qur'an 59: 20), \{And those who disbelieve and deny Our signs - those will be companions of the Fire; they will abide therein eternally\} (Qur'an 2: 39), \{But the ones who disbelieved and denied Our verses those are the companions of the Fire, abiding eternally therein; and wretched is the destination\} (Qur'an 64: 10), \{Indeed, those who disbelieve - never will their wealth or their children avail them against Allah at all, and those are the companions of the Fire; they will abide therein eternally\} (Qur'an 3: 116), \{Never think that the disbelievers are causing failure [to Allah] upon the earth. Their refuge will be the Fire - and how wretched the destination\} (Qur'an 24: 57).

\section{Independence}

Independence is one of the results of the culture of Tawhid. When mankind's sincere belief in Allah the Exalted exists, independence emerges. When independence emerges, mankind be- 
comes free of their own desires and the dictates of others. In addition, mankind becomes free of tyranny by virtue of depending solely on Allah. Once, Rustam, the leader of Persia asked the Companion Raba'i Ibn Amer, why did you come here, Raba'i replied, Allah sent us to get out of the worship of worship to worship the Lord of slaves and the narrowness of the world (this life) to the immensity of the Hereafter and from the tyranny of religions to the justice of Islam. Independence was among the Companions' daily practices. They solely dependent on Allah and trusted Him in every aspect of their lives, including sustenance and protection, and thus, they became brave, honest, courageous, and completely independent of relying on others and fearing none but Allah (Jabnoun, 2005). In the Holy Qur'an, Allah States: \{Say, "Never will we be struck except by what Allah has decreed for us; He is our protector." And upon Allah let the believers rely\} (Qur'an 9: 51), \{Say, “Indeed, there will never protect me from Allah anyone [if I should disobey], nor will I find in other than Him a refuge\} (Qur'an 72: 22), \{So rely upon Allah; indeed, you are upon the clear truth\} (Qur'an 27: 79), \{And will provide for him from where he does not expect. And whoever relies upon Allah - then He is sufficient for him. Indeed, Allah will accomplish His purpose. Allah has already set for everything a [decreed] extent? (Qur'an 65: 3), \{And rely upon the Exalted in Might, the Merciful\} (Qur'an 26: 217), \{Indeed, I have relied upon Allah, my Lord and your Lord. There is no creature but that He holds its forelock. Indeed, my Lord is on a path [that is] straight\} (Qur'an 11: 56), \{And rely upon Allah; and sufficient is Allah as Disposer of affairs\} (Qur'an 33: 3), \{Indeed, there is for him no authority over those who have believed and rely upon their Lord\} (Qur'an 16: 99), \{Allah - there is no deity except Him. And upon Allah let the believers rely\} (Qur'an 64: 13), \{And rely upon the Ever-Living who does not die, and exalt [Allah] with His praise. And sufficient is He to be, with the sins of His servants, Acquainted\} (Qur'an 25: 58), \{And why should we not rely upon Allah while He has guided us to our [good] ways. And we will surely be patient again st whatever harm you should cause us. And upon Allah let those who would rely [indeed] rely\} (Qur'an 14: 12), \{[Remember] when the hypocrites and those in whose hearts was disease said, "Their religion has deluded those [Muslims]." But whoever relies upon Allah - then indeed, Allah is Exalted in Might and Wise\} (Qur'an 8: 49), \{Indeed, it is Allah who is the [continual] Provider, the firm possessor of strength\} (Qur'an 51: 58), \{And there is no creature on earth but that upon Allah is its provision, and He knows its place of dwelling and place of storage. All is in a clear register\} (Qur'an 11: 6), \{Indeed, it is [promised] for you not to be hungry therein or be unclothed\} (Qur'an 20: 18), \{And in the heaven is your provision and whatever you are promised\} (Qur'an 51: 22), \{Indeed, your Lord extends provision for whom He wills and restricts [it]. Indeed, He is ever, concerning His servants, Acquainted and Seeing\} (Qur'an 17: 30), \{To Him belong the keys of the heavens and the earth. He extends provision for whom He wills and restricts [it]. Indeed, He is, of all things, Knowing\} (Qur'an 42: 12), \{Do they not see that Allah extends provision for whom He wills and restricts [it]? Indeed, in that are signs for a people who believe\} (Qur'an 30: 37), \{Allah extends provision for whom He wills of His servants and restricts for him. Indeed Allah is, of all things, Knowing\} (Qur'an 29: 62).

\section{Responsibility and Accountability}

Responsibility and accountability were part of the culture of the Companions of the Prophet Muhammad [Blessings and Peace be upon him]. The Companions knew that every action they were responsible to undertake, they, were also held accountable for. Also, they knew that every action taken will always retain either a positive or negative impact, and therefore, they were always striving to complete their tasks at the best of their knowledge and ability. This sense of responsibility and accountability engendered a sense of self-control in every action were taken in the Companions' daily lives. Additionally, it stimulated a sense of self-improvement, that is, 
in order to improve, a change from within should take place. In the Hadith, the Prophet Muhammad [Blessings and Peace be upon him] said "Every one of you is a shepherd and is responsible for his flock. The leader of the people is a guardian and is responsible for his subjects. A man is the guardian of his family and he is responsible for them. A woman is the guardian of her husband's home and his children and she is responsible for them. The servant of a man is a guardian of the property of his master and he is responsible for it. No doubt, every one of you is a shepherd and is responsible for his flock" (Sahih al-Bukhari, 6719) (3), "Allah loves when one of you does a job does it perfectly" (al-Bayhaqi) ${ }^{(4)}$. In the Holy Qur'an, Allah Says: \{Say, "Is it other than Allah, I should desire as a lord while He is the Lord of all things? And every soul earns not [blame] except against itself, and no bearer of burdens will bear the burden of another. Then to your Lord is your return, and He will inform you concerning that over which you used to differ\} (Qur'an 6: 164), \{So whoever does an atom's weight of good will see it\} (Qur'an 99: 7), \{And whoever does an atom's weight of evil will see it\} (Qur'an 99: 8), \{And, [O Muhammad], you are not [engaged] in any matter or recite any of the Qur'an and you [people] do not do any deed except that We are witness over you when you are involved in it. And not absent from your Lord is any [part] of an atom's weight within the earth or within the heaven or [anything] smaller than that or greater but that it is in a clear register\} (Qur'an 10: 61), \{Allah does not charge a soul except [with that within] its capacity. It will have [the consequence of] what [good] it has gained, and it will bear [the consequence of] what [evil] it has earned...\} (Qur'an 2: 286), \{For each one are successive [angels] before and behind him who protect him by the decree of Allah. Indeed, Allah will not change the condition of a people until they change what is in themselves...? (Qur'an 13: 11).

\section{Participation}

The act of participation was practiced by the Companions of the Prophet Muhammad [Blessings and Peace be upon him] as it was part of their culture. Examples of this act include, participation through consultations, giving good advices, forbidding evil, and enjoining goods. Consultation is equivalent to "Shura" in Islam, which aims at reaching consensus. To the Companions, the practice of "Shura" and humbly, giving good advices to one another, was a way of life, and as a result, they became more innovative, satisfied, efficient, adaptive, and better decision makers (Jabnoun, 2005). In the Hadith, the Prophet Muhammad [Blessings and Peace be upon him] said: "Religion is sincere advice" (Sahih Muslim) ${ }^{(5)}$, "Whoever amongst you sees an evil, he must change it with his hand; if he is unable to do so, then with his tongue; and if he is unable to do so, then with his heart; and that is the weakest form of Faith" (Sahih Muslim). In the Holy Qur'an, Allah Says: \{And let there be [arising] from you a nation inviting to [all that is] good, enjoining what is right and forbidding what is wrong, and those will be the successful\} (Qur'an 3: 104), \{Invite to the way of your Lord with wisdom and good instruction, and argue with them in a way that is best. Indeed, your Lord is most knowing of who has strayed from His way, and He is most knowing of who is [rightly] guided\} (Qur'an 16: 125), \{Indeed, Allah orders justice and good conduct and giving to relatives and forbids immorality and bad conduct and oppression. He admonishes you that perhaps you will be reminded\} (Qur'an 16: 90), \{Indeed, Allah commands you to render trusts to whom they are due and when you judge between people to judge with justice. Excellent is that which Allah instructs you. Indeed, Allah is ever

3 Sahih al-Bukhari is a collection of Hadith compiled by Imam Muhammad al-Bukhari (194 - 256 AH).

4 Al-Bayhaqi is collecter of Hadith. He was a scholar of fiqh of the Shafi'i school of thought $(384-458 \mathrm{AH})$.

5 Sahid Muslim is a collection of Hadith compiled by Imam Muslim ibn al-Hajjaj (202 - 261 AH). 
Hearing and Seeing\} (Qur'an 4: 58), \{O mankind, worship your Lord, who created you and those before you, that you may become righteous\} (Qur'an 2: 21), \{O you who have believed, do not consume usury, doubled and multiplied, but fear Allah that you may be successful\} (Qur'an 30: 130), \{O you who have believed, indeed, intoxicants, gambling, [sacrificing on] stone alters [to other than Allah], and divining arrows are but defilement from the work of Satan, so avoid it that you may be successful\} (Qur'an 5: 90), \{I convey to you the messages of my Lord, and I am to you a trustworthy adviser\} (Qur'an 7: 68), \{So by mercy from Allah, [O Muhammad], you were lenient with them. And if you had been rude [in speech] and harsh in heart, they would have disbanded from about you. So pardon them and ask forgiveness for them and consult them in the matter. And when you have decided, then rely upon Allah. Indeed, Allah loves those who rely [upon Him]\} (Qur'an 3: 159), \{And those who have responded to their lord and established prayer and whose affair is [determined by] consultation among themselves, and from what We have provided them, they spend\} (Qur'an 42: 38).

\section{Justice}

Justice was among the practiced cultural values of the Companions of the Prophet Muhammad [Blessings and Peace be upon him] in their daily lives. Islam encourages the practice of justice regardless of mankind differences and the end results. In the Holy Qur'an, Allah Says: \{Allah witnesses that there is no deity except Him, and [so do] the angels and those of knowledge - [that He is] maintaining [creation] in justice. There is no deity except Him, the Exalted in Might, the Wise\} (Qur'an 3: 18), \{Indeed, Allah orders justice and good conduct and giving to relatives and forbids immorality and bad conduct and oppression. He admonishes you that perhaps you will be reminded\} (Qur'an 1: 90), \{And O my people, give full measure and weight in justice and do not deprive the people of their due and do not commit abuse on the earth, spreading corruption\} (Qur'an 11: 85), \{[They are] avid listeners to falsehood, devourers of [what is] unlawful. So if they come to you, [O Muhammad], judge between them or turn away from them. And if you turn away from them - never will they harm you at all. And if you judge, judge between them with justice. Indeed, Allah loves those who act justly\} (Qur'an 5: 42), \{And for every nation is a messenger. So when their messenger comes, it will be judged between them in justice, and they will not be wronged\} (Qur'an 10: 47), \{Say, [O Muhammad], "My Lord has ordered justice and that you maintain yourselves [in worship of Him] at every place [or time] of prostration, and invoke Him, sincere to Him in religion." Just as He originated you, you will return [to life]\} (Qur'an 7: 29), \{And establish weight in justice and do not make deficient the balance\} (Qur'an 55: 9), \{O you who have believed, be persistently standing firm for Allah, witnesses in justice, and do not let the hatred of a people prevent you from being just. Be just; that is nearer to righteousness. And fear Allah; indeed, Allah is Acquainted with what you do\} (Qur'an 5: 8), \{And do not approach the orphan's property except in a way that is best until he reaches maturity. And give full measure and weight in justice. We do not charge any soul except [with that within] its capacity. And when you testify, be just, even if [it concerns] a near relative. And the covenant of Allah fulfill. This has He instructed you that you may remember\} (Qur' an 6: 152), \{And if two factions among the believers should fight, then make settlement between the two. But if one of them oppresses the other, then fight against the one that oppresses until it returns to the ordinance of Allah. And if it returns, then make settlement between them in justice and act justly. Indeed, Allah loves those who act justly\} (Qur'an 49: 9), \{O mankind, indeed We have created you from male and female, and made you peoples and tribes that you may know one another. Indeed, the most noble of you in the sight of Allah is the most righteous of you. Indeed, Allah is Knowing and Acquainted\} (Qur'an 49: 13), \{And We place the scales of justice for the Day of Resurrection, so no soul will be treated unjustly at all. And if there is [even] the weight of a mustard seed, We will bring it forth. And sufficient are We as accountant\} (Qur'an 21: 47). 


\section{Dignity, Respect, and Privacy}

Dignity, respect, and privacy rights for all mankind are stressed by Islam. In Islam, these rights are emphasized and protected for all mankind while alive or dead, irrespective of their race, gender, color, or religion. The Companions of the Prophet Muhammad [Blessings and Peace be upon him] understood the significance of these human rights for all mankind and acted upon them in their daily lives. In the Holy Qur'an and in the Hadith, there are many evidences which stress these rights. This is evident in the teaching of the Prophet Muhammad [Blessings and Peace be upon him] where he said when a visitor is at the host's door, the visitor must knock at the door thrice and wait for permission to enter. If the permission was not granted, the visitor the visitor must leave (Muslim \& Bukhari). In another Hadith, Prophet Muhammad [Blessings and Peace be upon him] said that the burial of the dead should be accelerated (Musnad Ahmad: 196) ${ }^{(6)}$. In the Holy Qur'an, Allah States: \{And We have certainly honored the children of Adam and carried them on the land and sea and provided for them of the good things and preferred them over much of what We have created, with [definite] preference\} (Qur'an 17: 70), \{O you who have believed, avoid much [negative] assumption. Indeed, some assumption is sin. And do not spy or backbite each other. Would one of you like to eat the flesh of his brother when dead? You would detest it. And fear Allah; indeed, Allah is Accepting of repentance and Merciful (Qur'an 49: 12), \{O you who have believed, do not enter houses other than your own houses until you ascertain welcome and greet their inhabitants. That is best for you; perhaps you will be reminded\} (Qur'an 24: 27), \{O you who have believed, do not enter the houses of the Prophet except when you are permitted for a meal, without awaiting its readiness. But when you are invited, then enter...\} (Qur'an 33: 53), \{And when the children among you reach puberty, let them ask permission [at all times] as those before them have done. Thus does Allah make clear to you His verses; and Allah is Knowing and Wise\} (Qur'an 24: 59), \{O you who have believed, let those whom your right hands possess and those who have not [yet] reached puberty among you ask permission of you [before entering] at three times: before the dawn prayer and when you put aside your clothing [for rest] at noon and after the night prayer. [These are] three times of privacy for you. There is no blame upon you, nor upon them beyond these [periods], for they continually circulate among you - some of you, among others. Thus does Allah make clear to you the verses; and Allah is Knowing and Wise\} (Qur'an 24: 58).

\section{Trust}

Infusing trust is a vital practice that all mankind should not neglect. Building trust is an essential task that requires a hard work to accomplish. Distrusting others may come from different venues such as suspicious acts, deception, dishonesty, negative assumptions, and many others. One effective way to establish trust is to abandon the practice of negative assumptions. The Companions of the Prophet Muhammad [Blessings and Peace be upon him] established mutual trust through openness and directness practices (Jabnoun, 2005). In the Holy Qur'an, Allah Says: \{O you who have believed, avoid much [negative] assumption. Indeed, some assumption is sin. And do not spy or backbite each other. Would one of you like to eat the flesh of his brother when dead? You would detest it. And fear Allah; indeed, Allah is Accepting of repentance and Merciful\} (Qur'an 24: 58), \{They are not, but [mere] names you have named them - you and your forefathers - for which Allah has sent down no authority. They follow not except assumption and what [their] souls desire, and there has already come to them from their Lord guidance\} (Qur'an 53: 23), \{And they have thereof no knowledge. They follow not except assumption,

6 Musnad Ahmad is a collection of Hadith collected by Imam Ahmad ibn Hanbal (164 - 241 AH). 
and indeed, assumption avails not against the truth at all\} (Qur'an 53: 28), \{And most of them follow not except assumption. Indeed, assumption avails not against the truth at all. Indeed, Allah is Knowing of what they do\} (Qur'an 10: 36), \{Unquestionably, to Allah belongs whoever is in the heavens and whoever is on the earth. And those who invoke other than Allah do not [actually] follow [His] "partners." They follow not except assumption, and they are not but falsifying\} (Qur'an 10: 66), \{And if you obey most of those upon the earth, they will mislead you from the way of Allah. They follow not except assumption, and they are not but falsifying? (Qur'an 6: 116), \{And [for] their saying, "Indeed, we have killed the Messiah, Jesus, the son of Mary, the messenger of Allah." And they did not kill him, nor did they crucify him; but [another] was made to resemble him to them. And indeed, those who differ over it are in doubt about it. They have no knowledge of it except the following of assumption. And they did not kill him, for certain\} (Qur'an 4: 157), \{Those who associated with Allah will say, "If Allah had willed, we would not have associated [anything] and neither would our fathers, nor would we have prohibited anything." Likewise did those before deny until they tasted Our punishment. Say, "Do you have any knowledge that you can produce for us? You follow not except assumption, and you are not but falsifying"' (Qur' an 6: 148), \{And among the People of the Scripture is he who, if you entrust him with a great amount [of wealth], he will return it to you. And among them is he who, if you entrust him with a [single] silver coin, he will not return it to you unless you are constantly standing over him [demanding it]. That is because they say, "There is no blame upon us concerning the unlearned." And they speak untruth about Allah while they know [it]\} (Qur'an 3: 75).

\section{Dialogue}

The dialogue was part of the culture of the Companions of the Prophet Muhammad [Blessings and Peace be upon him]. Moreover, the value of the dialogue was always shared at all levels within the culture of the Companions regardless of their age, gender, race, or ethnic background. Further, during the life of the Prophet Muhammad [Blessings and Peace be upon him], the dialogue practice took place between Muslims and non-Muslims. In the Islamic culture, dialogue is not considered as surrender, rather, a way of life. Therefore, whether or not it occurs via dialogue, surrender is undesirable (Jabnoun, 2005). In the Holy Qur'an, Allah Says: \{Then whoever argues with you about it after [this] knowledge has come to you - say, "Come, let us call our sons and your sons, our women and your women, ourselves and yourselves, then supplicate earnestly [together] and invoke the curse of Allah upon the liars [among us]"'? (Qur'an 3: 61), \{Say, "O People of the Scripture, come to a word that is equitable between us and you - that we will not worship except Allah and not associate anything with Him and not take one another as lords instead of Allah." But if they turn away, then say, "Bear witness that we are Muslims [submitting to Him]"' (Qur'an 3: 64), \{Have you not considered the one who argued with Abraham about his Lord [merely] because Allah had given him kingship? When Abraham said, "My Lord is the one who gives life and causes death," he said, "I give life and cause death." Abraham said, "Indeed, Allah brings up the sun from the east, so bring it up from the west." So the disbeliever was overwhelmed [by astonishment], and Allah does not guide the wrongdoing people\} (Qur'an 2: 258), \{And those who argue concerning Allah after He has been responded to - their argument is invalid with their Lord, and upon them is [His] wrath, and for them is a severe punishment\} (Qur'an 42: 16), \{And when it is said to them, "Come, the Messenger of Allah will ask forgiveness for you," they turn their heads aside and you see them evading while they are arrogant\} (Qur'an 63: 5), \{And when it is said to them, "Come to what Allah has revealed and to the Messenger," you see the hypocrites turning away from you in aversion\} (Qur'an 4: 61), \{And when it is said to them, "Come to what Allah has revealed and 
to the Messenger," they say, "Sufficient for us is that upon which we found our fathers." Even though their fathers knew nothing, nor were they guided?\} (Qur'an 5: 104), \{And that He might make evident those who are hypocrites. For it was said to them, "Come, fight in the way of Allah or [at least] defend." They said, "If we had known [there would be] fighting, we would have followed you". They were nearer to disbelief that day than to faith, saying with their mouths what was not in their hearts. And Allah is most Knowing of what they conceal\} (Qur'an 3: 167), \{Say, "Come, I will recite what your Lord has prohibited to you. [He commands] that you not associate anything with Him, and to parents, good treatment, and do not kill your children out of poverty; We will provide for you and them. And do not approach immoralities - what is apparent of them and what is concealed. And do not kill the soul which Allah has forbidden [to be killed] except by [legal] right. This has He instructed you that you may use reason"') (Qur'an 6: 151), \{Say, “O disbelievers, I do not worship what you worship, Nor are you worshippers of what I worship, Nor will I be a worshipper of what you worship, Nor will you be worshippers of what I worship, For you is your religion, and for me is my religion\} (Qur'an 109: 1-6).

\section{Cost efficiency}

The Prophet Muhammad [Blessings and Peace be upon him] taught his Companions to be efficient. This is evident by instructing them not to use more than the minimum amount of water necessary when performing ablution even if they were using the water of a river (Musnad Ahmad: 6768). Some Conpanions were poor, where some others were rich. However, luxurious life was not part of the Companions. Even with the rich ones who could afford the luxury, they were not interested in indulgence. When it comes to spending, Islam encourages moderate spending and condemns extravagance (Jabnoun, 2005). In the Holy Qur'an, Allah Says: $\{O$ children of Adam, take your adornment at every masjid, and eat and drink, but be not excessive. Indeed, He likes not those who commit excess\} (Qur'an 7: 31), \{And He it is who causes gardens to grow, [both] trellised and untrellised, and palm trees and crops of different [kinds of] food and olives and pomegranates, similar and dissimilar. Eat of [each of] its fruit when it yields and give its due [Zakah] on the day of its harvest. And be not excessive. Indeed, He does not like those who commit excess\} (Qur'an 6: 141), \{And give the relative his right, and [also] the poor and the traveler, and do not spend wastefully\} (Qur'an 17: 26), \{Indeed, the wasteful are brothers of the devils, and ever has Satan been to his Lord ungrateful\} (Qur'an 17: 27).

\section{Time efficiency}

In the West, time means money. However, in Islam, it means 'Life'. Allah prescribed to all mankind a time span before death. Thus, time is very precious and should not go waste, and rather, should be efficiently utilized in acquiring good deeds for the sake of Allah. Mankind is held accountable for the utilization of time. Therefore, time utilization should always be in matters which please Allah. The Companions of the Prophet Muhammad [Blessings and Peace be upon him] efficiently utilized their times in seeking knowledge, worshipping Allah, and working (Jabnoun, 2005). Noting the importance of time utilization, in the Hadith, the Prophet Muhammad [Blessings and Peace be upon him] said, "Man's feet will not move on the Day of Resurrection before he is asked about his life, how did he consume it, his knowledge, what did he do with it, his wealth, how did he earn it and how did he dispose of it, and about his body, how did he wear it out" (Jami al-Tirmidhi) ${ }^{(7)}$. In another Hadith, the Prophet [Blessings and Peace be upon him], also said "Take advantage of five before five: your youth before your old

7 Jami al-Timidhi is a collection of Hadith compiled by Imam Abu Isa Muhammad at-Tirmidhi (209 - 279 $\mathrm{AH})$. 
age, your health before your illness, your riches before your poverty, your free time before your work, and your life before your death" (Al-Bayhaqi: 9575).

\section{Caring and Sharing}

Brotherhood in Islam is among the tasks that Islam has established amid the believers. As a result, the believers are encouraged to establish the caring and sharing practices among one another, especially when someone is experiencing some difficulties. Caring eventually leads to sharing and mutual support which are significantly vital to overcome hardships. The culture of the Companions of the Prophet Muhammad [Blessings and Peace be upon him] was filled with caring and sharing practices. They cared about one another, the animals, and the surrounding environment. Their living community had a sense of collectiveness and collectively, they felt as if they were one body in feeling the pain of anyone in the community. The caring and sharing practices of the Companions were for the sake of Allah and as a result, they were highly motivated in doing so (Jabnoun, 2005). In the Hadith, the Prophet Muhammad [Blessings and Peace be upon him] said, "Muslims are like one body of a person; if the eye is sore, the whole body aches, and if the head aches, the whole body aches" (Sahih Muslim: 2586), "None of you [truly] believes until he loves for his brother that which he loves for himself" (Sahih Muslim: 45 and Sahih al-Bukhari: 13). In the Qur'an, Allah Says: \{And they give food in spite of love for it to the needy, the orphan, and the captive, [Saying], "We feed you only for the countenance of Allah. We wish not from you reward or gratitude\} (Qur'an 76: 8-10), \{And [also for] those who were settled in al-Madinah and [adopted] the faith before them. They love those who emigrated to them and find not any want in their breasts of what the emigrants were given, but give [them] preference over themselves, even though they are in privation. And whoever is protected from the stinginess of his soul - it is those who will be the successful\} (Qur'an 59: 9), \{O you who have believed, do not violate the rites of Allah or [the sanctity of] the sacred month or [neglect the marking of] the sacrificial animals and garlanding [them] or [violate the safety of] those coming to the Sacred House seeking bounty from their Lord and [His] approval. But when you come out of ihram, then [you may] hunt. And do not let the hatred of a people for having obstructed you from al-Masjid al-Haram lead you to transgress. And cooperate in righteousness and piety, but do not cooperate in sin and aggression. And fear Allah; indeed, Allah is severe in penalty\} (Qur'an 5: 2), \{And hold firmly to the rope of Allah all together and do not become divided. And remember the favor of Allah upon you - when you were enemies and He brought your hearts together and you became, by His favor, brothers. And you were on the edge of a pit of the Fire, and He saved you from it. Thus does Allah make clear to you His verses that you may be guided; (Qur'an 3: 103).

\section{Mercy towards Humans, Animals, and the Environment}

Among the Attributes of Allah is mercy and among his Names is "the Merciful". Islam upholds mercy to all mankind, animals, the environment, and every living creature which Allah created. Everything that Allah created belongs to Him, thus, mankind ought to care about Allah's creation. Throughout the history, Muslims, created Islamic endowments called "Awqaf" whom sole purpose is sheltering and feeding animals. Islam instructs Muslims not to cut trees, nor to pollute wells. During wars, Islam instruction is not to burn books for the purpose of protecting the environment and the civilization of the opponent even when the opponent is an enemy. The culture of the Companions of the Prophet Muhammad [Blessings and Peace be upon him] was filled with mercy towards themselves, others, animals, and the environment. They were taught by their leader, the Prophet Muhammad [Blessings and Peace be upon him] on many occasions (Jabnoun, 2005). In the Hadith, the Prophet [Blessings and Peace be upon him] said, "Be mer- 
ciful on the earth, and you will be shown mercy from Who is above the heavens. The womb is named after Ar-Rahman, so whoever connects it, Allah connects him, and whoever severs it, Allah severs him" (Jami al-Tirmidhi: 1924), "The Compassionate One has mercy on those who are merciful. If you show mercy to those who are on the earth, He Who is in the heaven will show mercy to you" (Sunan Abi Dawud: 4941) ${ }^{(8)}$. In the Holy Qur'an, Allah Says: \{There has certainly come to you a Messenger from among yourselves. Grievous to him is what you suffer; [he is] concerned over you and to the believers is kind and merciful\} (Qur'an 9: 128), \{Muhammad is the Messenger of Allah; and those with him are forceful against the disbelievers, merciful among themselves. You see them bowing and prostrating [in prayer], seeking bounty from Allah and [His] pleasure. Their mark is on their faces from the trace of prostration. That is their description in the Torah. And their description in the Gospel is as a plant which produces its offshoots and strengthens them so they grow firm and stand upon their stalks, delighting the sowers - so that Allah may enrage by them the disbelievers. Allah has promised those who believe and do righteous deeds among them forgiveness and a great reward\} (Qur'an 48: 29).

\section{Eagerness to Learn}

The first verse from the Holy Qur'an that was revealed to the Prophet Muhammad [Blessings and Peace be upon him] included the word "Read". In the Holy Qur'an, Allah Says: \{Recite (Read) in the name of your Lord who created, Created man from a clinging substance, Recite, and your Lord is the most Generous, Who taught by the pen, Taught man that which he knew not...\} (Qur'an 96: 1-5) Ever since, the revelation of this verse, an educational revolution among Muslim had taken place. Because, the verse instructed to read, the Companions of the Prophet Muhammad [Blessings and Peace be upon him] were eager to learn. Consequently, learning how to read and write among Muslims, men and women, increased, resulting in a rapid increase in their level of literacy (Jabnoun, 2005). Islam encourages seeking and teaching knowledge which can be evident in the Holy Qur'an and in the Hadith. In the Holy Qur'an, Allah Says: \{So High [above all] is Allah, the Sovereign, the Truth. And, [O Muhammad], do not hasten with [recitation of] the Qur'an before its revelation is completed to you, and say, "My Lord, increase me in knowledge"\} (Qur'an 20: 114), \{O you who have believed, when you are told, "Space yourselves" in assemblies, then make space; Allah will make space for you. And when you are told, "Arise," then arise; Allah will raise those who have believed among you and those who were given knowledge, by degrees. And Allah is Acquainted with what you do\} (Qur' an 58: 11), \{Is one who is devoutly obedient during periods of the night, prostrating and standing [in prayer], fearing the Hereafter and hoping for the mercy of his Lord, [like one who does not]? Say, "Are those who know equal to those who do not know?" Only they will remember [who are] people of understanding\} (Qur'an 39: 9), \{So know, [O Muhammad], that there is no deity except Allah and ask forgiveness for your sin and for the believing men and believing women. And Allah knows of your movement and your resting place\} (Qur'an 47: 19), \{And among people and moving creatures and grazing livestock are various colors similar. Only those fear Allah, from among His servants, who have knowledge. Indeed, Allah is Exalted in Might and Forgiving\} (Qur'an 35: 28), \{And these examples We present to the people, but none will understand them except those of knowledge\} (Qur'an 29: 43), \{And they will say, "If only we had been listening or reasoning, we would not be among the companions of the Blaze\} (Qur'an 67: 10), \{Allah witnesses that there is no deity except Him, and [so do] the angels and those of knowledge - [that He is] maintaining [creation] in justice. There is no deity except Him, the Exalted in Might, the Wise\} (Qur'an 3: 18), \{But those firm in knowledge among them and the believers

8 Sunan Abu Dawood is a collection of Hadith, collected by Abu Dawood (202 - 275 AH) 
believe in what has been revealed to you, [O Muhammad], and what was revealed before you. And the establishers of prayer [especially] and the givers of zakah and the believers in Allah and the Last Day - those We will give a great reward\} (Qur'an 4: 161), \{And it is He who spread the earth and placed therein firmly set mountains and rivers; and from all of the fruits He made therein two mates; He causes the night to cover the day. Indeed, in that are signs for a people who give thought\} (Qur'an 13: 3), \{And in yourselves. Then will you not see? (Qur'an 51: 21), \{Say, [O Muhammad], "Travel through the land and observe how He began creation. Then Allah will produce the final creation. Indeed Allah, over all things, is competent"' (Qur'an 29: 20), \{Have they not traveled through the earth and observed how was the end of those before them? They were greater than them in power, and they plowed the earth and built it up more than they have built it up, and their messengers came to them with clear evidences. And Allah would not ever have wronged them, but they were wronging themselves\} (Qur'an 30: 9). In the Hadith, the Prophet Muhammad [Blessings and Peace be upon him] said, "If Allah wants to do good to a person, He makes him comprehend the religion. I am just a distributor, but the grant is from Allah. (And remember) that this nation (true Muslims) will keep on following Allah's teachings strictly and they will not be harmed by any one going on a different path till Allah's order (Day of Judgment) is established" (Sahih al-Bukhari: 71), "Whoever takes a path upon which to obtain knowledge, Allah makes the path to Paradise easy for him" (Jami al-Tirmidhi: 2646), "Seeking knowledge is a duty upon every Muslim" (Sunan Ibn Majah: 224) (9), "Whoever comes to this mosque of mine, and only comes for a good purpose, such as to learn or to teach, his status is like that of one who fights in Jihad in the cause of Allah. Whoever comes for any other purpose, his status is that of a man who is keeping an eye on other people's property" (Sunan Ibn Majah: 227), "Do not wish to be like anyone except in two cases. (The first is) A person, whom Allah has given wealth and he spends it righteously; (the second is) the one whom Allah has given wisdom (the Holy Qur'an) and he acts according to it and teaches it to others" (Sahih al-Bukhari: 73), "O Allah! Bestow on him the knowledge of the Book (Qur'an)" (Sahih al-Bukhari: 75), "The example of guidance and knowledge with which Allah has sent me is like abundant rain falling on the earth, some of which was fertile soil that absorbed rain water and brought forth vegetation and grass in abundance. (And) another portion of it was hard and held the rain water and Allah benefited the people with it and they utilized it for drinking, making their animals drink from it and for irrigation of the land for cultivation. (And) a portion of it was barren which could neither hold the water nor bring forth vegetation (then that land gave no benefits). The first is the example of the person who comprehends Allah's religion and gets benefit (from the knowledge) which Allah has revealed through me (the Prophets and learns and then teaches others. The last example is that of a person who does not care for it and does not take Allah's guidance revealed through me (He is like that barren land)" (Sahih al-Bukhari: 79), "Three persons will have a double reward: 1. A Person from the people of the scriptures who believed in his Prophet (Jesus or Moses) and then believed in the Prophet Muhammad (i.e. has embraced Islam), 2. A slave who discharges his duties to Allah and his master, 3. A master of a woman-slave who teaches her good manners and educates her in the best possible way (the religion) and manumits her and then marries her" (Sahih al-Bukhari: 97), "He who introduced some good practice in Islam, which was followed after him (by people) he would be assured of reward like one who followed it, without their rewards being diminished in any respect. And he who introduced some evil practice in Islam, which had been followed subsequently (by others), he would be required to bear the burden like that of one who followed this (evil practice) without their's being diminished in any respect" (Sahih Muslim: 1017), "He who called (people) to

9 Sunan Ibn Majah is a collection of Hadith, collected by Imam Muhammad Ibn Majah (209 - 273 AH). 
righteousness, there would be reward (assured) for him like the rewards of those who adhered to it, without their rewards being diminished in any respect. And he who called (people) to error, he shall have to carry (the burden) of its sin, like those who committed it, without their sins being diminished in any respect" (Sahih Muslim: 2674).

\section{Collectiveness}

Islam stresses the concepts of collectiveness and cooperation. As a religion, Islam is a universal and a collective religion for all mankind irrespective of age, race, or gender. Islam encourages the practice of cooperation and unification. Group-based practices with clear visions, missions, goals, and objectives, are also promoted by Islam. Hence, Islam promotes the concept of "Synergy" for the betterment of effectiveness and efficiency in achieving predefined goals. The Companions of the Prophet Muhammad [Blessings and Peace be upon him] culture was filled with collective efforts in spreading Islam, learning, teaching, helping one another, working with one another, enjoining goods, forbidding evil, and many others. These efforts had an ultimate goal to achieve and that is pleasing Allah (Jabnoun, 2005). In the Holy Qur'an, Allah Says: \{And hold firmly to the rope of Allah all together and do not become divided. And remember the favor of Allah upon you - when you were enemies and He brought your hearts together and you became, by His favor, brothers. And you were on the edge of a pit of the Fire, and He saved you from it. Thus does Allah make clear to you His verses that you may be guided\} (Qur'an 3: 103), \{And let there be [arising] from you a nation inviting to [all that is] good, enjoining what is right and forbidding what is wrong, and those will be the successful $\}$ (Qur'an 3: 104), \{O you who have believed, do not violate the rites of Allah or [the sanctity of] the sacred month or [neglect the marking of] the sacrificial animals and garlanding [them] or [violate the safety of] those coming to the Sacred House seeking bounty from their Lord and [His] approval. But when you come out of ihram, then [you may] hunt. And do not let the hatred of a people for having obstructed you from al-Masjid al-Haram lead you to transgress. And cooperate in righteousness and piety, but do not cooperate in sin and aggression. And fear Allah; indeed, Allah is severe in penalty\} (Qur'an 5: 2). In the Hadith, the Prophet Muhammad [Blessings and Peace be upon him] said, "Allah's Hand is with the Jama'ah (Group)" (Jami al-Tirmidhi: 2166).

\section{The Outcomes of Implementation}

From an organizational cultural perspective, having these aforementioned values amid the founders and all members within the organization engenders a cultural environment that fears none but Allah and His punishment, and hopes for His mercy, forgiveness, and ultimately to enter paradise. Therefore, members of this culture by all means, will always promote good behaviors and reject wrong doings while engaging in all of the organization's internal and/ or external affairs. This culture is a focused culture which creates unity of purpose. It instills a unity of destiny, motivation, competition, and a sense of independence. Further, it promotes responsibility, accountability, participation, cooperation, openness, justice, and benevolence. Additionally, it endorses dignity, respect, privacy and trust. It stimulates a sense of dialogue and negotiation, and promotes, efficiency, productivity, discipline, caring, sharing, and mercy towards humans, animals, and the environment. It encourages learning, pondering, innovation, motivation, competition, creativity, and collective efforts. This culture provides a high level of consistency, flexibility, adaptability, and satisfaction. Finally, with the implementation of these values, organizations will, undoubtedly, become just, productive, efficient, competitive, reputable, and will have an outstanding identity. 


\section{Conclusion}

The organizational culture is an imperative aspect to the success of the organization. Thus, organizations should always strive to create and implement the best culture that eventually enables them to achieve their long term goals and overall organizational strategies. In this paper, the concept of organizational culture from a Western and Islamic perspective was discussed. Further, an Islamic Organizational Culture Model was presented for Muslims and Muslim owned organizations for future reference and implementation. As foundations, the model included sixteen cultural values which resembled the culture of the Companions of the Prophet Muhammad [Blessing and Peace be upon him]. These values are Tawhid, Unity of Purpose, Belief in the Hereafter, Reward, and Punishment, Independece, Responsibility and Accountability, Participation, Justice, Dignity, Respect, and Privacy, Trust, Dialouge, Cost efficiency, Time efficiency, Caring and Sharing, Mercy towards Humans, Animals, and the Environment, Eagerness to Learn, and Collectiveness. Lastly, based on the discussion presented by the model, outcomes of implementation were presented. 


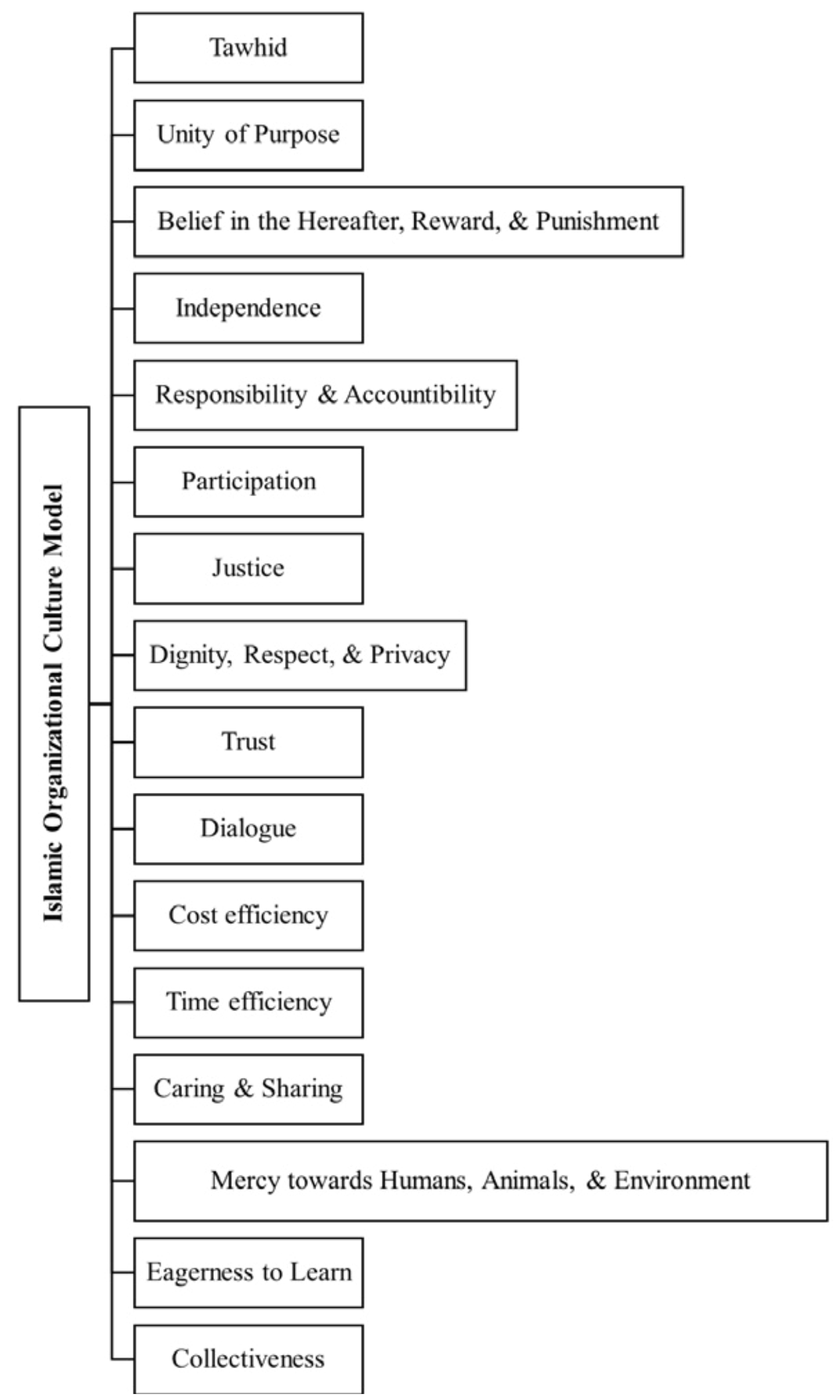

Figure 1: The Islamic Organizational Culture Model 


\section{References}

Apaydin, M., Jones, G., George, J., \& Belkhodja, O. (2017). Contemporary Management. London: McGraw Hill Education.

Barney, J. (1986). Organizational Culture, Can it be a source of competitive advantage. Academy of Management Review, 656-665.

Denison, D. (1990). Corporate Culture and Organizational Effectiveness. New York: John Wiley and Sons.

Gardner, M. (1985). Creating a Corporate Culture for the Eighties. Business Horizons, 59-63.

Harrison, S., \& Corley, K. (2011). Clean Climbing, Carabiners, and Cultural Cultivation: Developing an Open-Systems Perspective of Culture. Organization Science, 391412 .

Jabnoun, N. (2005). Islam and Management. Riyadh: International Islamic Publishing House.

Kets, F., \& Miller, D. (1986). Personality, Culture and Organization. Academy of Management Review, 266-279.

Nelson, Q. (2013). Principles of Organizational Behavior Realities and Challenges. South-Western, Cengage Learning.

Schein, E. (1985). Organizational Culture and Leadership. San Francisco: Jossey-Bass.

Smircich, L. (1983). Concepts of Organizational Analysis. Administrative Science Quarterly, 342. 